\title{
Shells in the German Baroque: geometry is technology
}

\author{
V. Compán, F. Escrig \& M. Cámara \\ Department of Continuum Mechanics and Structural Analysis, \\ University of Sevilla, Spain
}

\begin{abstract}
Shells are forms that base their behaviour in their geometry. From antiquity the art of building has been conceived as the ability to span and grew with little pieces, using bricks and stones, until there were great closed spaces. Arches, vaults and domes work because of their geometrical disposition more than because of their intrinsic strengthening.

From their invention, domes have been subjected to a process of optimization that arises slowly to diminish thickness at the same time that it increases covered areas. How the thick Roman Pantheon dome is converted, almost with the same span in a thin skin in the Hagia Sophia, explains with clarity the path from heavy to light buildings. Maybe Saint Vital in Ravenna is the end of this process, not surpassed for twelve centuries by Renaissance nor Ottoman domes. Saint Vital was the culmination of lightness thanks to the use of a special kind of hollow brick.

When some architects were impelled to build in the Baroque style with short budgets and pour technological advice, they thought that the solution was to be found in the geometry and not in the materials. Architects such as Borromini, Guarini and Vittone were the masters who taught a new young generation headed by Juvara, Fischer and the Dienzenhofer family.

Their proposals for double curved single layer domes were really shells, thinner than ever executed before. Spherical dome caps realised at this time were as thin as twenty centimetres, with or without ribs. Vaults composed of sectors of spheres and cylinders were varied and showed a complexity not seen since the Muslim domes.

The complexity of Baroque domes has not be conveniently studied until now, may be because engineers think more in terms of mathematical analysis than in terms of geometrical concepts.
\end{abstract}


This is the reason we have planned a geometrical approach by using the immense potential that computer design programs such as CATIA and ABAQUS brings to the architectonical analysis.

The series of churches and other constructions studied are extensive and in this paper we will include only some of the more surprising Balthazar Neuman designs such as the Chapel in the Banz Monastery, Residence Chapel in Würzburg Palace and Fourteen Saints Basilica.

The program of the advanced research includes the geometrical definition of the architectonical models, most of them checked in situ, the graphical determination, the mathematical FEM definition, and the final analysis and dimensioning.

The main objective is to demonstrate that the basis of the optimal behaviour is the special geometry considered for each design that considers only membrane stresses instead of shell stresses. Bending is really acting in borders and edges and not in the general surface as occurs in concrete and steel shells. Baroque was the inventor of membranes as conceived, actually with such complexity that none of the great concrete builders tried to build.

It is a thesis well founded in the research that we present in this paper. Keywords: historical masonry building, FE modelling, shell behaviour.

\section{Introduction}

Shell structures, as we actually know them (made in reinforced concrete), find their origin in the middle of the $20^{\text {th }}$ century, when authors like Félix Candela or Eduardo Torroja made very important buildings with the Shell Theory as a basis.

In this material, the interaction between concrete and steel allowed doublecurvature surfaces designs in which bending was easy to resist.

The basis of the ecclesiastical buildings design in the $18^{\text {th }}$ century, mainly in Central Europe, allowed the investigation in double-curvature surfaces to span great distances. The result was surprising, because the thin masonry roofs of this buildings, which were able to span more than 14 meters with very low bending, was possible.

The definition of these new geometries and their implementation were possible thanks to the high knowledge of the work with wood to make complex forms and the experience in masonry constructions gained from previous generations.

\section{Baroque structures}

The evolution of the great masonry roofs, made after the Renaissance, begin with Guarino Guarini. His continuous search for originality drove him to conceive great building works with a clearly innovative geometrical basis. The search for grouping and juxtaposition of "spatial cells" allowed him to go into the study of spatial solutions rather more complex than Renaissance ones in depth.

Many of these churches are organized from an octagon in plan as a basis. This geometry allows that the intersections between the different cells were flat 
arches, which can be solved by two diagonally arches on which two cylindrical sectors lean. We can find one of these cases in St. Fillippo Neri, Turin (1679). [1, 2] The use of geometric plane resources to define the roof is his better defence to adapt double-curvature surfaces to a plane edge.

In the case of Ste. Anne Royale (1663), a Latin cross-plan church with a central dome on scallops and juxtaposed with four independent "spatial cells" which are octagonal in plan, the trouble is to define the double-curvature roof of these cells itself. They were generated by crocked plane arches which are crowned by a horizontal hexagon in the keystone which has a very clear function: to absorb the geometrical incompatibility. Obviously, this solution isn't a continuous double-curvature surface, but Guarini found one advantage in it: all the intersections between the different "spatial cells" are arches, avoiding quadratic ones.

One of the first and clearest examples is the Sta. Inmaculata Concezione Chapel. It has an easy composition in plan but a geometrical complexity that hadn't been raised before: the quadratic intersections.
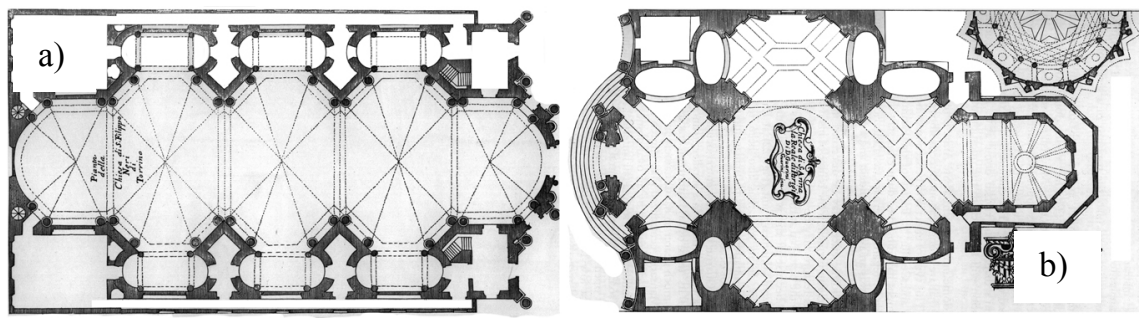

Figure 1: $\quad$ a) St. Filippo Neri, Turín (1679), b) Ste. Anne Royale (1663).
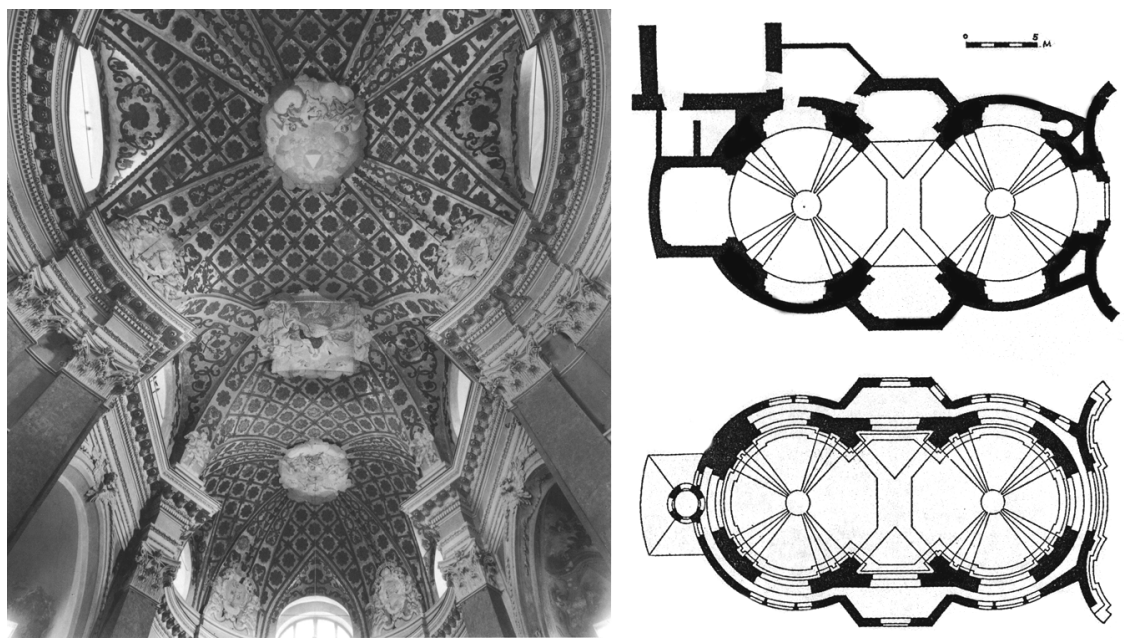

Figure 2: $\quad$ Sta. Inmaculata Concezione. 
The experimentation that Guarino Guarini began was continued by the Dientzenhofer Family, in which there were great architects, stonemasons, builders, etc [3]. Within its extensive work, made mainly in Bohemia and the Czech Republic, we have chosen two of the most representative buildings because of their geometrical expression, than is significantly higher than what we have seen before.

One of them, and as a starting point, is St. Nicholas Church [4], in the Small Side of Prague, where it was possible to solve the "pulsating juxtaposition" of the spatial cells initiated by Guarino Guarini. This effect consists in a sequence of dilated and contracted spaces and it's possible only with the creation of warped ribs.
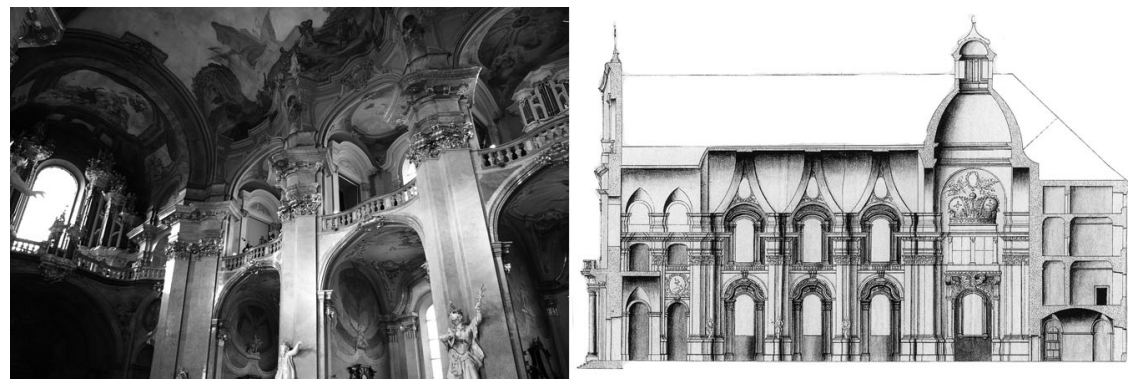

Figure 3: $\quad$ St. Nicholas Church, in the Small Side of Prague (1703).

But the problem is that, in this case, technical experts aren't able to give a satisfactory answer and the final solution is closer to a barrel vault than a real double-curvature surface.

It will wait to the development of a group of churches in which this problem is solved: St. Joseph, in Obořiště (1702) [5]; Sta Klara, in Cheb (1708); Sta Margaret, in Brĕnov (1709); or the Church in Benedictine Convent in Banz, in Bad Staffelstein (1698), the most important of all of them, by Johann Dientzenhofer.

The work made by Dientzenhofer family was continued by the German architect Balthasar Neumann. With him, the constructive solution evolves with the same geometrical basis. We emphasize the Chapel in the Residence, in Würzburg (1710) and the Vierzehnheiligen Basilica.

\section{Study cases and initial hypothesis}

The churches we have studied in depth are by Dientzenhofer Family and Balthasar Neumann. All these buildings have roofs constructed in thin masonry. 1.- The Benedictine Convent Church, in Banz (1698).

2.- The Residence (princebishops' palace) Chapel, in Würzburg (1720).

3.- Vierzehnheiligen Basilica. (1742). 
The analysis has been made using the application Abaqus 6.7-1, based on the Finite Elements Method, applying continuous elements of reduced integration, eight-node hexahedra (C3D8R) and ten-node quadratic tetrahedral (C3D10) [6].

We have considered the material as elastic and lineal [7].

1. $\gamma=1700 \mathrm{Kg} / \mathrm{m}^{3}$

2. $\mathrm{E}=10 \mathrm{E} \mathrm{Ton} / \mathrm{m}^{2}$ and the material is elastic and lineal in the considered range.

3. $v=1 / 6$

The loads applied are due to the own weight of the masonry roof. The loads due to wind forces are driven to the lateral walls by a wood roof sited over the masonry one.

\section{The Benedictine Convent Church in Banz}

This one-nave church present a longitudinal sequence with three spaces: the access one, where the organ is situated; the central one, which has greater dimensions and is the main space; and the last one, with the same scale than the first one and where the altar is situated.

The most important compositive element is the warped rib that organizes the complete space. The Dienzenhofer Family could make this geometrically complex rib very skilfully, considering the geometrical resources at that moment. Without knowledge in quadratic intersections, Johann Dientzenhofer designed these ribs on the basis of plane analysis. He didn't work with standard double-curvature surfaces that, in fact, it wasn't possible with the oval-in-plan spaces he designed and the same in section, so he established first the ribs and then the surface of the roof adjusting it to the built edges. In this church, the geometry of the ribs is the result of the intersection of two cylinders, one in a vertical position and the other in a horizontal position, both with different sizes [8].

The roof of this church in Banz spans 13,7 meters. It's $30 \mathrm{~cm}$ thick and is made by brick masonry with $14 \times 28 \times 4,5 \mathrm{~cm}$ as dimensions of one brick and joints, probably lime joints, which are from 1,5 to $2 \mathrm{~cm}$ thick. The surface is reinforced by the warped ribs, which have a greater thickness. The solution of these warped ribs is closer to two plane arches that lean one on the other in the keystone.
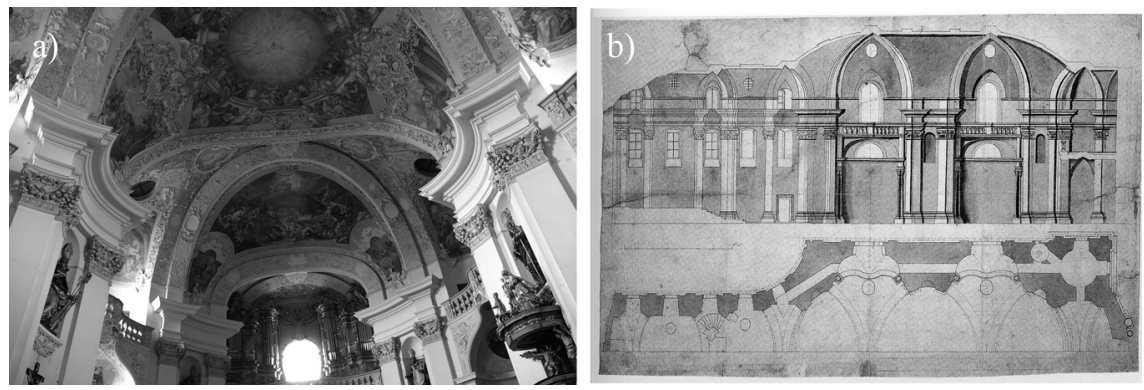

Figure 4: Benedictine Convent Church (1698). a) Interior warped rib, b) Section and plan. 
88 Structural Studies, Repairs and Maintenance of Heritage Architecture XI

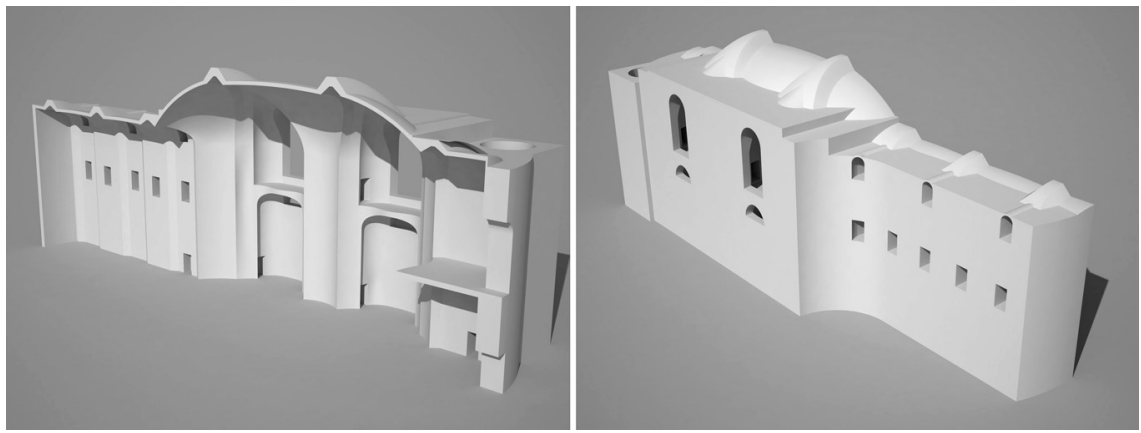

Figure 5: $\quad$ Structural model for the meshing with 3D solids.
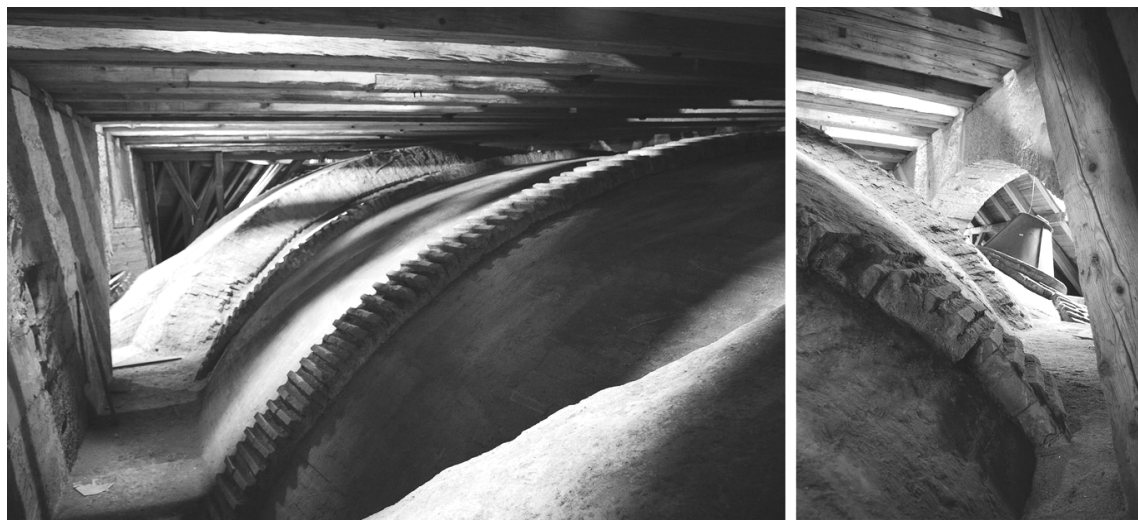

Figure 6: Convent Chapel, in Banz (1698). Masonry roof extrados.
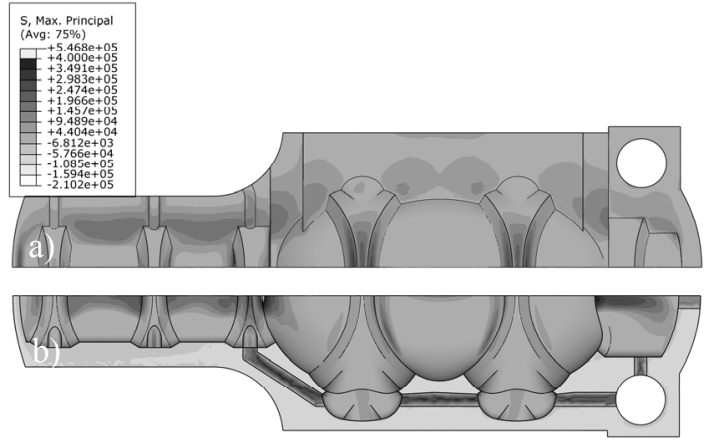

Figure 7: $\quad$ Principal tension stresses (Pa). a) Masonry roof in the trasdos. b) Masonry roof in the extrados. 
Johann Dientzenhofer designed an inverted "V" in the ribs' keystone which gives stiffness to the ribs and contributes to the three-dimensional stability counteracting horizontal loads and working the ribs in pairs.

The joint between the different surfaces occurs in the warped ribs, where the thickness is higher to increase the stability and the compression strength. There isn't any kind of rib reinforcement in the different intersections between the main surfaces and other secondary elements like lunettes.

\section{The Residence Chapel, in Würzburg}

This one-nave church is generated by the intersection between three oval in plan main domes with their greater axis in a longitudinal position and another two smaller domes, oval in plan too but with their greater axis in a transversal position $[9,10]$. The result is a spatial composition with the "pulsating juxtaposition" principle as the basic concept.

In this chapel, the warped rib is dissolved and even becomes a transition surface between the two adjacent main domes. In this case, we don't find a reinforcement warped rib that solved the intersection. The solution is closer to the intersection of two double-curvature surfaces where the arris is in the intrados.

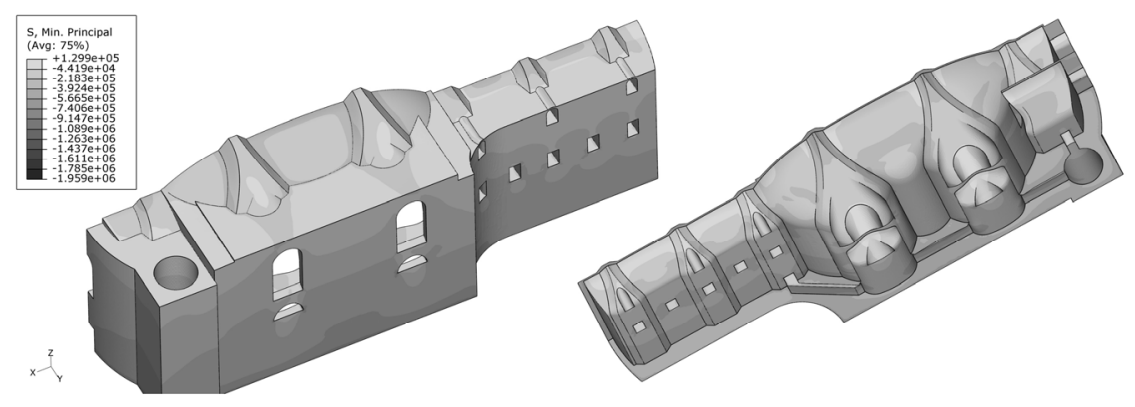

Figure 8: $\quad$ Principal compression stresses (Pa).

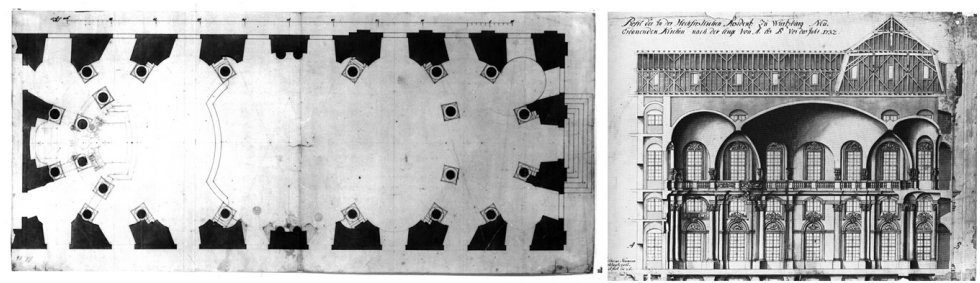

Figure 9: Residence Chapel plan, Würzburg (1710). 
The main domes are made by masonry in only one $30 \mathrm{~cm}$ thick layer, which increases its thickness in $15 \mathrm{~cm}$ near the base to reinforce them. Each dome presents a series of $45 \times 45 \mathrm{~cm}$ in section ribs which are radially situated and built at the same time than the rest of the dome.

The two smaller domes of the spatial composition have an only one $30 \mathrm{~cm}$ thick layer without any kind of reinforcement and the arrangement of the bricks in this masonry is due more to an adjustment to the double-curvature surface, than to a structural reason, but it changes significantly the structural behaviour in comparing with the Chapel in Banz by Johann Dientzenhofer.
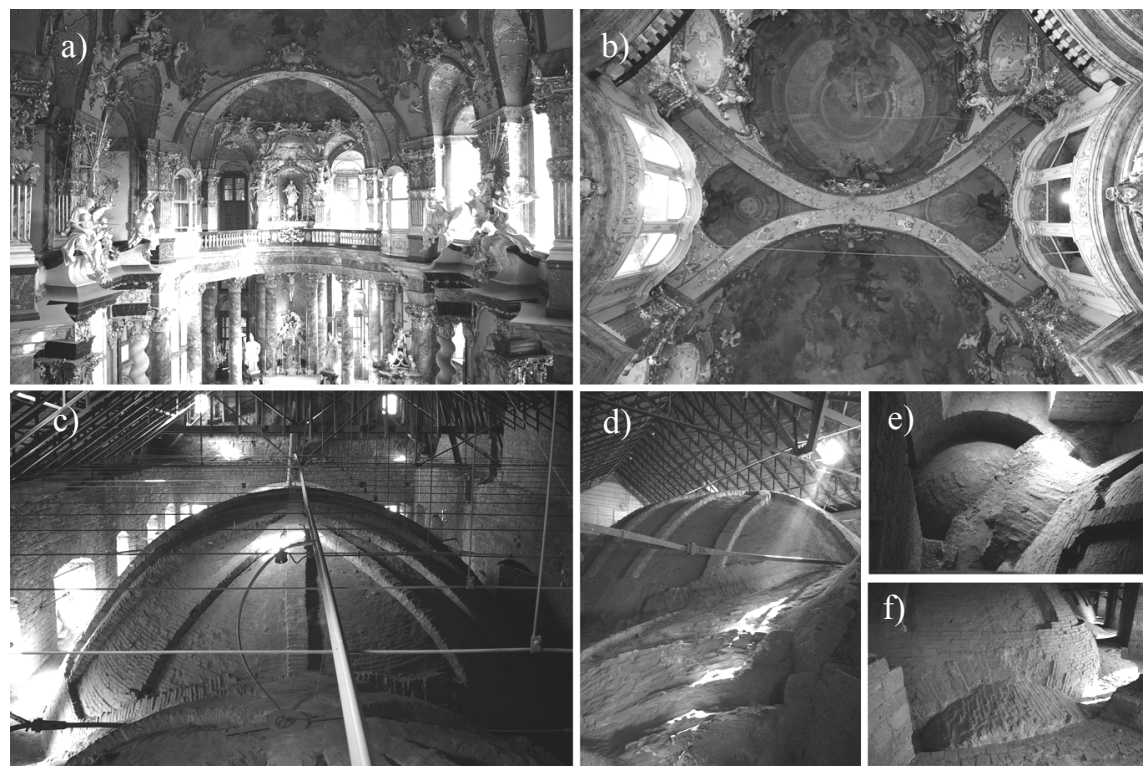

Figure 10: a),b) Interior views, c),d) Extrados of the main dome, e), f) Masonry details.
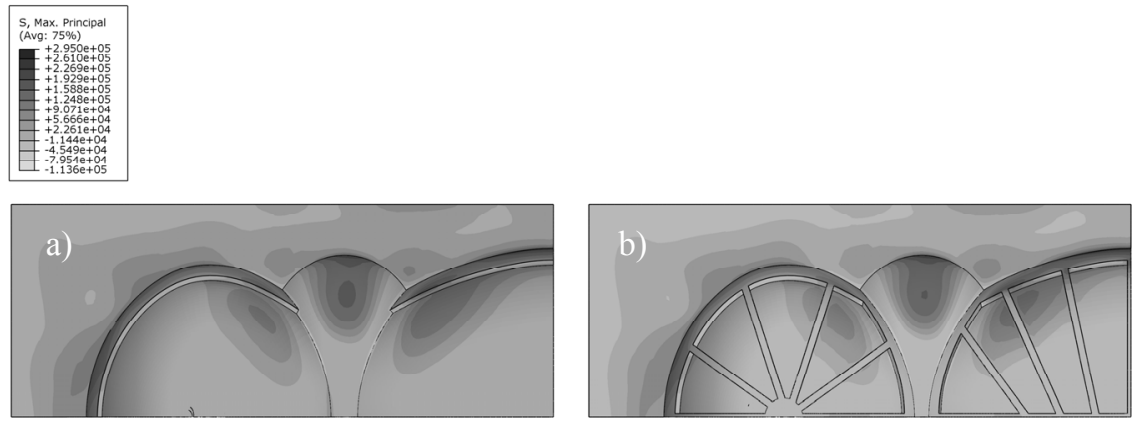

Figure 11: Principal tension stresses $(\mathrm{Pa})$ in the extrados. a) Model without ribs, b) Model with ribs. 

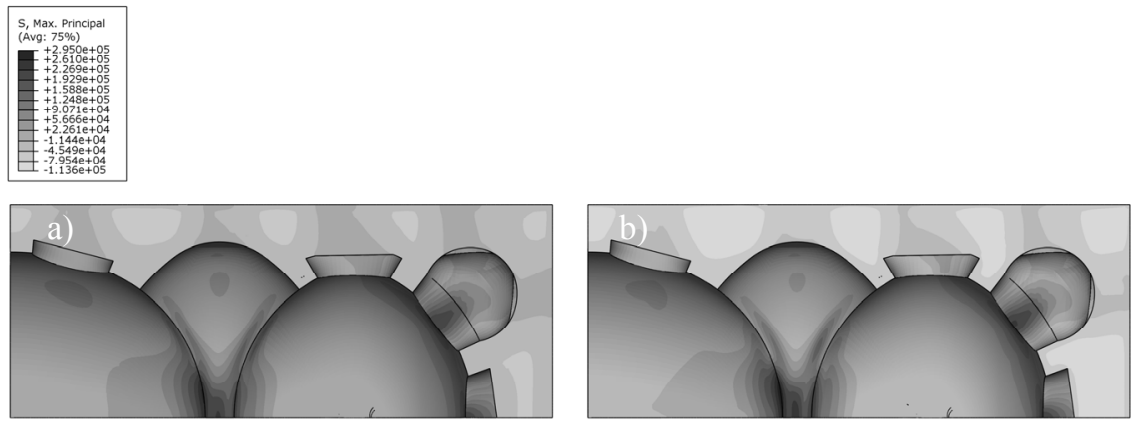

Figure 12: Principal tension stresses $(\mathrm{Pa})$ in the intrados. a) Model without ribs, b) Model with ribs.
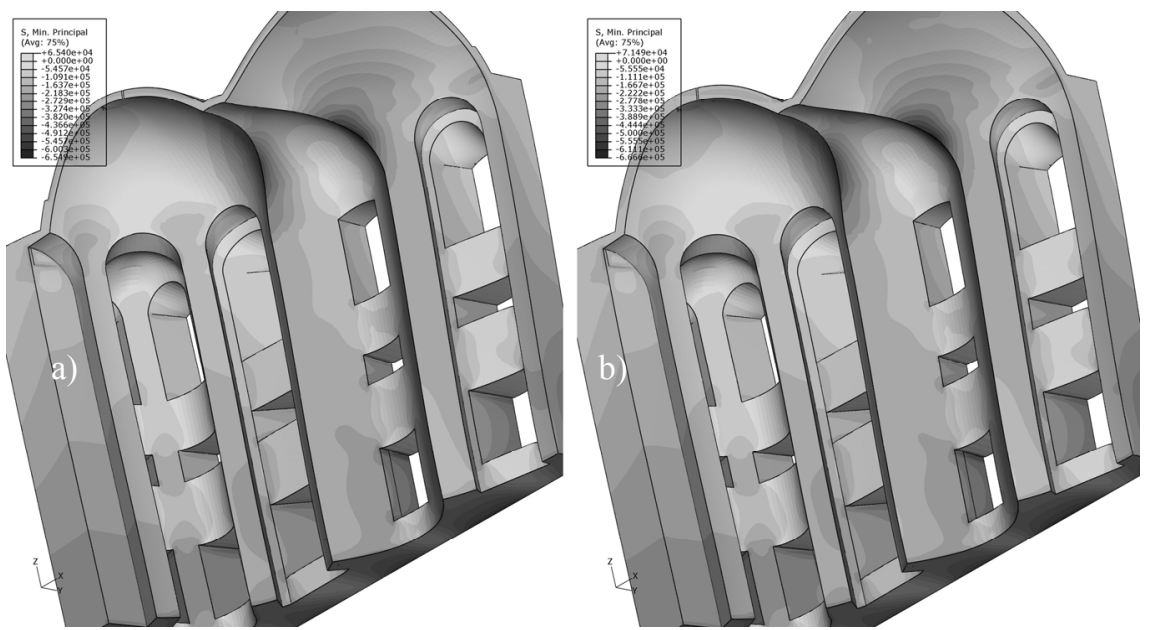

Figure 13: Principal compression stresses $(\mathrm{Pa})$ in the intrados. a) Model without ribs, b) Model with ribs.

The results based on elastic analysis show tension areas with values that brick masonry couldn't support, so plastic analysis is necessary in order to determinate stresses more precisely, and thus, to make a value judgment with data that would be closer to the real behaviour.

\section{Vierzehnheiligen Basilica}

But the most interesting work, regarding a real structural shell behaviour, is the solution that Balthasar Neumann adopted in Vierzehnheiligen Basilica, whose construction couldn't complete owing to the fact that he died when the walls' cornice was being built. 
The solution of the roof is completely different than the previous case, not only because of the scale and the reinforcement ribs absence, but because of the change of the material.

The geometrical design has the same basis than the Chapel in the Residence in Würzburg [11, 12], but its scale is greater. This Latin cross-plan basilica has three naves and one transept crowned by spherical domes.
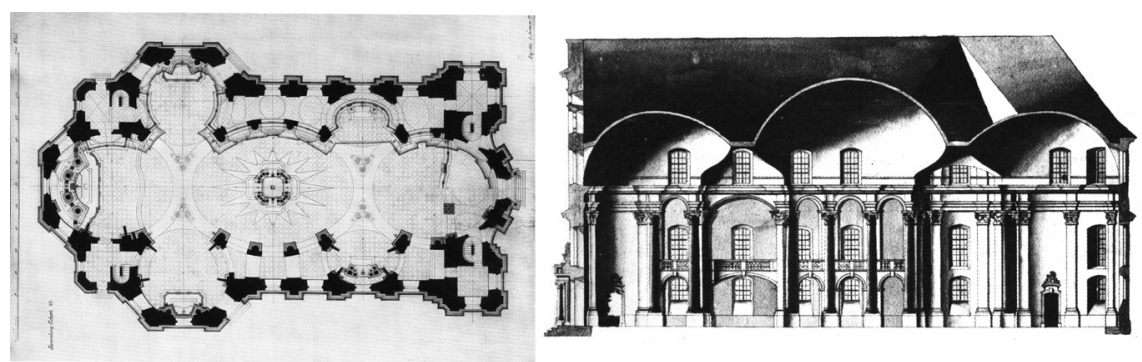

Figure 14: Vierzehnheiligen Basilica plan.
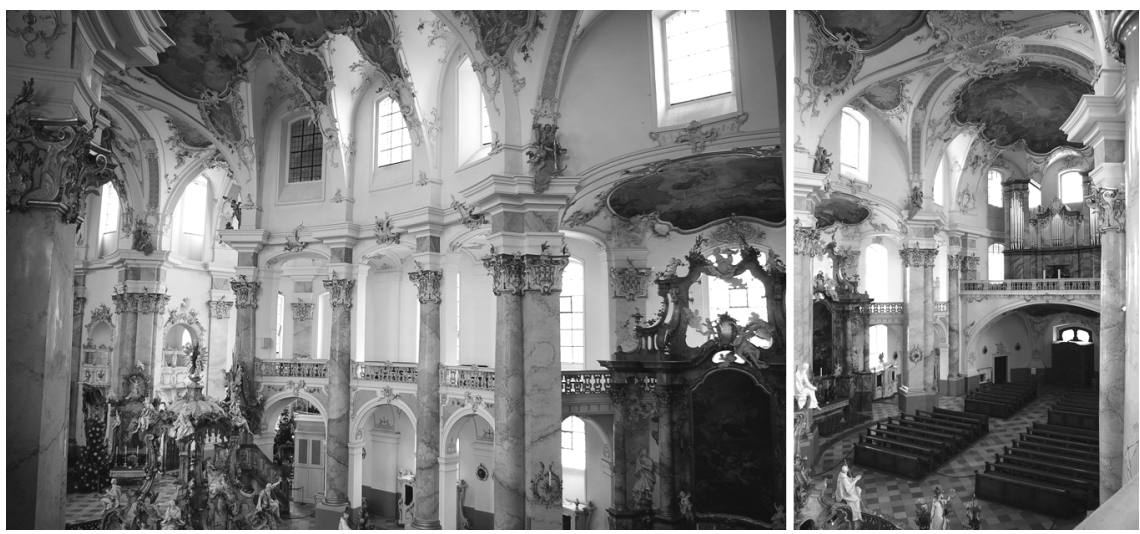

Figure 15: Interior views of the Vierzehnheiligen Basilica.

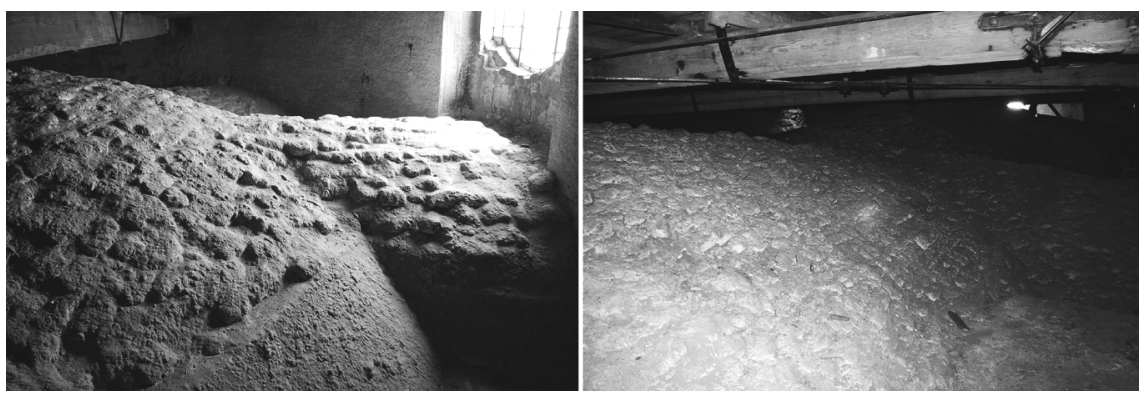

Figure 16: Views of the extrados roof in Vierzehnheiligen Basilica. 


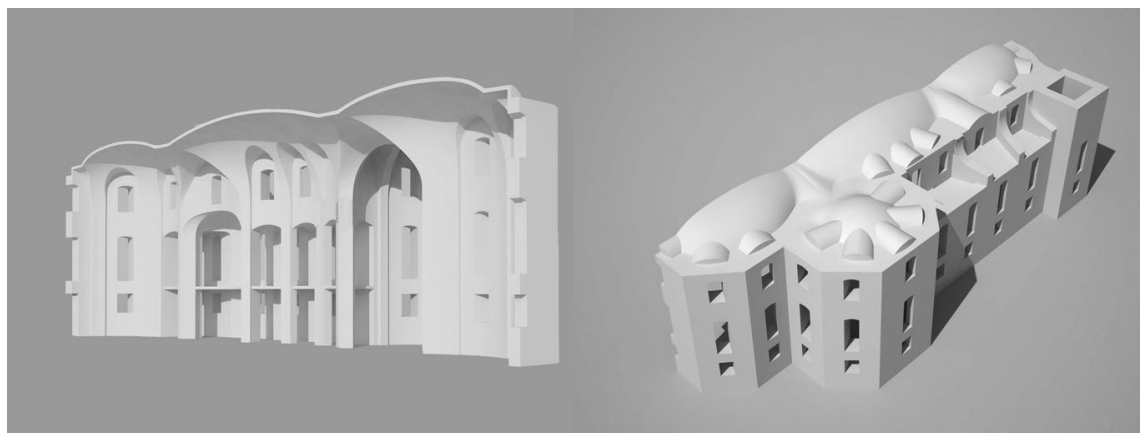

Figure 17: Structural model for the meshing with 3D solids.
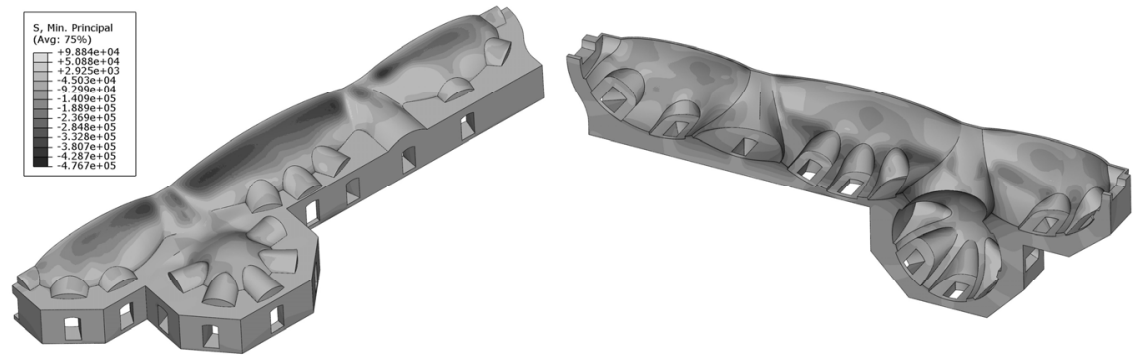

Figure 18: $\quad$ Principal compression stresses $(\mathrm{Pa})$.

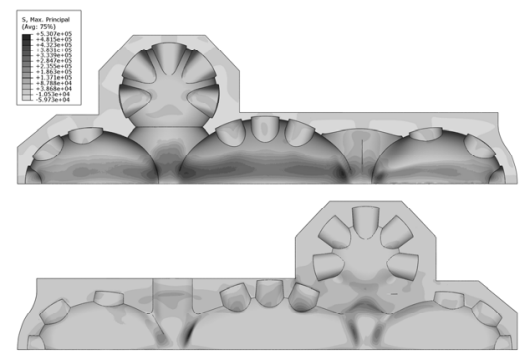

Figure 19: Principal tension stresses $(\mathrm{Pa})$.

It is a $30 \mathrm{~cm}$ thick roof without any kind of structural reinforcement in the intersection between the domes and made using a sedimentary stone called "tuff", which was extracted from a river nearby [13].

\section{Conclusions}

Although it is difficult to establish some conclusions at the present state of the research, we want to point out the interest of this kind of construction so little studied and so interesting. Our interest is going into the non lineal study of this 
kind of thin masonry roofs in depth to the better establishment of their structural behaviour and the study of all the Baroque proposals that are so differentiated of other styles, developed before or after.

Analyzing the different solutions for the warped rib that we have presented, it can be said that the only one that works like a discharging arch is the rib in the convent church in Banz.

Likewise it's confirmed that the structural behaviour of all the studied roofs is closer to a shell behaviour than to a plane one. Bending is low in general and only some very located areas, where tension could be decisive, are detected.

The solution in Vierzehnheiligen is the closest to this kind of behaviour, due to the final surface is more continuous than in the rest of the cases, without any kind of additional structural reinforcement.

Anyway, it's important to point out that the radial ribs of the roof in the Residence, in Würzburg, aren't structural. We have could check that the stress state doesn't change significantly if we pay attention to the results of the analysis of the models with and without ribs.

\section{References}

[1] H.A. Meek, Guarino Guarini and his architecture. Yale University Press. 1988

[2] Christian Norberg-Schulz, Weltgeschichte Der Architektur, Spätbarock Und Rokoko. Deutche Erlags-anstalt Stuttgart.1985

[3] Hans Zimmer, Die Dientzenhofer. Rosenheimer

[4] Wolf Hartmut Roidl, Die Kurvierten Sakralräume Des Christoph Dientzenhofer. Tuduv-Studien. 1995

[5] Milada Vilímková, Johannes Brucker. Dientzenhofer, Rosenheimer Verlagshaus. 1989

[6] Hidaka, K., Aoki, T., Kato, S. 1989"Structural Stability and profile in the Dome of Hagia Sofia, Istambul'. Structural Repair and Maintenance of Historical Buildings. Computational Mechanics Publications. Southampton.

[7] Lourenço, P.B. 1998 "Experimental and numerical issues in the modelling of the mechanical behaviour of masonry. Structural Analysis of Historical Constructions II. CIMNE. Barcelona.

[8] Werner Müller, Von Guarino Guarini Bis Balthasar Neumann. Michael Imhof, Petersberg Verlag. 2002

[9] Wilfried Hansmann, Balthasar Neumann. Dumont. 1999

[10] R. Sedlmaier, R. Pfister, Die Fürstibischöfliche Residenz Zu Würzburg. München Verlegt Bei Georg Müller. 1923

[11] Otto, Christian F, Space into Light. The Churches of Balthasar Neumann, Mit Press Series. 1979

[12] Sammlung Eckert, Aus Balthasar Neumanns Baubüro. Mainfränkisches Museum

[13] Franzl Ludwig, Balthasar Neumann, Dachwerke Seiner Landkirchen, Technischen Universität Berlin 